\title{
UPAYA PENINGKATAN PENGETAHUAN TENTANG PENCEGAHAN HEAT STROKE PADA CALON JAMAAH HAJI
}

\author{
Increasing Knowledge Of Candidates For Pilgrims About Heat Stroke Prevention
}

\author{
Indriana Noor Istiqomah ${ }^{1}$, Achlish Abdillah ${ }^{1}$, Laili Nur Azizah ${ }^{1}$ \\ ${ }^{1}$ Prodi D3 Keperawatan Fak. Keperawatan Unej Kampus Lumajang \\ J1. Brigjend Katamso Lumajang 67312 \\ email: indrinoor@unej.ac.id
}

\begin{abstract}
ABSTRAK
Ibadah haji merupakan implementasi rukun Islam ke-5 yang sangat dirindukan oleh hamper seluruh umat muslim, sehingga berbagai upaya akan dilakukan untuk bisa menjalankan ibadah di tanah suci, namun perbedaan suhu antara di Indonesia dan di Arab Saudi dapat menimbulkan masalah kesehatan pada jamaah haji. Selama musim haji terjadi pada saat cuaca panas, maka risiko terjadinya heat stroke pada jamaah haji akan selalu ada. Tingginya angka kematian jamaah haji akibat heat stroke semestinya bisa dicegah dengan perilaku pencegahan yang baik ditunjang dengan perilaku sehat yang lain. Untuk bisa melakukan tindakan pencegahan yang tepat, perlu pengetahuan yang cukup tentang hal tersebut.

Tujuan kegiatan ini adalah meningkatkan pengetahuan calon jamaah haji di wilayah KUA Sukodono, Kabupaten Lumajang tentang heat stroke dan upaya pencegahannya. Sedangkan manfaat kegiatan ini adalah memberikan pembekalan dan pengetahuan yang cukup tentang heat stroke kepada calon jamaah haji, serta upaya pencegahan yang harus dilakukan oleh setiap jamaah haji.

Metode kegiatan dilakukan dengan tahapan sebagai berikut: 1) Promosi kesehatan, penyampaian materi tentang heat stroke, disertai penayangan video penderita heat stroke pada musim haji sebelumnya; 2) Praktik aklimatisasi dan upaya pencegahan oleh calon jamaah haji; 3) Evaluasi hasil pelaksanaan.

Hasil dari kegiatan ini adalah calon jamaah haji mengetahui upaya yang dapat dilakukan untuk mencegah heat stroke dari tanah air sampai ke tanah suci. Tindak lanjut yang perlu dilakukan adalah adanya kegiatan sejenis kepada calon jamaah haji 1 (satu) sampai 2 (dua) bulan sebelum masa keberangkatan jamaah ke tanah suci, agar proses aklimatisasi dan penyesuaian diri bisa berlangsung dengan baik. Pada kegiatan pengabdian selanjutnya disarankan pemberian materi dilakukan berulang kali sehingga materi yang disampaikan dapat selalu diingat oleh jamaah sampai ke tanah suci.
\end{abstract}

Kata kunci: pencegahan heat stroke, calon jamaah haji

\section{ABSTRACT}

Hajj is the implementation of fifth pillars of Islam that is sorely missed by almost all Muslims, so that efforts will be made to allow them to worship in the holy land, but the temperature difference between the Indonesian and Saudi Arabia can cause health problems for pilgrims. During the pilgrimage season occurs during hot weather, then the risk of heat stroke on the pilgrims will always be there. The high rate of death due to heat stroke pilgrims should be prevented with good preventive health behaviors supported by other healthy behaviors. To be able to do a proper precautions, it should be enough knowledge about it.

The purpose of this activity is to increase knowledge of pilgrims in the area of KUA Sukodono, Lumajang about heat stroke and prevention efforts. While the benefits of this activity is to provide briefing and enough knowledge about heat stroke to pilgrims, as well as preventive measures to be taken by each pilgrim.

Method of activities carried out in stages as follows: 1) The health promotion, delivery of materials on heat stroke, along with videos about heat stroke patients in previous Hajj season; 2) Practice acclimatization and prevention by pilgrims candidates; 3) Evaluation of the results of the implementation.

The results of these activities are pilgrims candidates know the effort that can be done to prevent heat stroke from the homeland to the holy land. Follow-up needs to be done is the same activity to pilgrims 1 (one) to 2 (two) months prior to the departure of pilgrims to the holy land, so that the process of acclimatization and adaptation can take place properly. At the next activities, suggested giving the material is repeated so that the material presented can be always remembered by pilgrims.

Keywords: prevention of heat stroke, pilgrims 


\section{PENDAHULUAN}

Ibadah haji merupakan implementasi rukun Islam ke-5 yang sangat dirindukan oleh hamper seluruh umat muslim, sehingga berbagai upaya akan dilakukan untuk bisa berangkat dan menjalankan ibadah di tanah suci. Namun ada hal yang terkadang dilupakan oleh calon jamaah haji, bahwa ibadah haji tidak hanya memerlukan istithaah (kemampuan) financial, namun juga istithaah spiritual dan kesehatan. Perbedaan suhu antara di Indonesia dan di Arab Saudi dapat menimbulkan masalah kesehatan pada jamaah haji. Musim haji mulai tahun 2015 yang terjadi pada bulan Agustus sampai September, berlangsung pada saat musim panas, dan diperkirakan suhu pada saat puncak haji akan mencapai $55^{\circ} \mathrm{C}$. Kondisi seperti ini diperkirakan akan berlangsung sampai tahun 2030.

Masalah kesehatan yang terjadi pada jamah calon haji akibat paparan cuaca panas yang ekstrim di Arab Saudi, diakibatkan oleh terjadinya dehidrasi atau kekurangan cairan yang dapat menimbulkan heat stroke atau memperburuk penyakit yang telah diderita sejak dari tanah air, bahkan dapat menimbulkan kematian. Selama musim haji terjadi pada saat cuaca panas (bulan Juli Oktober), maka risiko terjadinya heat stroke pada jamaah haji akan selalu ada. Tingginya angka kematian jamaah haji pada kondisi cuaca panas yang ekstrim akibat heat stroke semestinya bisa dicegah dengan perilaku pencegahan yang baik, ditunjang dengan perilaku sehat yang lain.

Adapun tindakan pencegahan heat stroke yang bisa dilakukan oleh calon jamaah haji meliputi: penyesuaian suhu panas sebelum berangkat, keluar rumah pada siang hari: bawa minum, minum 5-6 1 atau 1 gelas per jam, hindari kopi, makan buah segar, gunakan sunscreen, dll.

Untuk bisa melakukan tindakan pencegahan yang tepat, perlu pengetahuan yang cukup tentang hal tersebut. Oleh karena itu setiap calon jamaah perlu mendapatkan pembekalan dan pengetahuan yang cukup tentang heat stroke, dampak, serta upaya pencegahan yang harus dilakukan oleh setiap calon jamaah haji melalui promosi/pendidikan kesehatan. Pendidikan kesehatan sangat diperlukan oleh $\mathrm{CJH}$ mengingat hampir seluruh jamaah baru pertama kali pergi ke tanah suci. Dengan pendidikan kesehatan ini,
CJH memiliki gambaran masalah kesehatan apa saja yang bisa terjadi di tanah suci sehingga dapat melakukan persiapan fisik sejak di tanah air.

\section{METODE}

Kegiatan pengabdian ini dilaksanakan di KUA Sukodono, bekerja sama dengan takmir Masjid Al Muhajirin Perumahan Sukodono-Lumajang, serta mahasiswa Akper Pemkab Lumajang. Metode yang digunakan dalam kegiatan ini adalah memberikan penyuluhan tentang materi heat stroke, disertai penayangan video gambaran penderita heat stroke pada musim haji sebelumnya yang dilakukan dalam waktu 1 hari. Setelah itu calon jamaah haji diminta untuk melakukan upaya pencegahan yang sudah bisa dilakukan sejak di tanah air (aklimatisasi dan adaptasi). Evaluasi hasil kegiatan dilakukan 2 (dua) minggu setelah pelaksanaan penyuluhan.

\section{HASIL}

Kegiatan pengabdian ini dilaksanakan di KUA Sukodono, bekerja sama dengan takmir Masjid Al Muhajirin Perumahan SukodonoLumajang, diikuti oleh calon jamaah haji di wilayah KUA Sukodono, Kabupaten Lumajang yang berjumlah 44 orang. Kegiatan diawali dengan tahap pemberian materi dan diakhiri dengan evaluasi.

\section{Tahap pemberian materi}

Saat pemberian materi, peserta antusias memperhatikan materi yang disajikan, terutama saat video dampak heat stroke terhadap jamaah ditayangkan. Sebagian besar peserta baru pertama kali ke tanah suci, dan materi heat stroke adalah materi baru bagi peserta. Pemberian materi dilaksanakan selama 50 menit, dilanjutkan dengan 15 menit untuk diskusi dan tanya jawab. Pada saat penyuluhan, disampaikan tentang:

a. Heat stroke yang meliputi:
1) Pengertian
2) Faktor risiko
3) Gejala
4) Penanganan
5) Dampak
6) Upaya pencegahan

b. Perilaku sehat yang menunjang upaya pencegahan terjadinya heat stroke.

Kegiatan ini mendapatkan sambutan baik dari peserta, karena manasik/penyuluhan 
kesehatan jarang diberikan kepada calon jamaah haji (CJH) sampai di tingkat kecamatan. Hal ini terbukti dengan banyak $\mathrm{CJH}$ yang mengajukan pertanyaan, dan pernyataan $\mathrm{CJH}$ yang tidak ingin mengalami heat stroke seperti dalam video yang ditayangkan.

\section{Tahap Praktik}

Setelah pemberian materi, $\mathrm{CJH}$ diminta untuk mulai melakukan upaya pencegahan heat stroke di rumah sesuai kemampuan $\mathrm{CJH}$ meliputi: penyesuaian suhu panas sebelum berangkat (aklimatisasi), keluar rumah pada siang hari: bawa minum, minum 5-6 1 atau 1 gelas per jam, hindari kopi, makan buah segar, gunakan sunscreen, dll.

\section{Tahap Evaluasi}

Pada tahap evaluasi, $80 \% \quad \mathrm{CJH}$ memiliki pengetahuan yang baik tentang pencegahan heat stroke, namun $50 \% \mathrm{CJH}$ masih merasa berat untuk melakukan aklimatisasi dan adaptasi pola sehari-hari seperti menghindari kopi dan mengkonsumsi buah lebih banyak.

\section{SIMPULAN}

Dalam upaya menurunkan angka kejadian heat stroke pada jamaah (calon) haji, maka dapat dilakukan upaya preventif, salah satunya melalui penyampaian informasi atau pendidikan kesehatan tentang heat stroke. Khusus untuk heat stroke, dengan mengetahui upaya pencegahan yang bisa dilakukan, maka diharapkan $\mathrm{CJH}$ sudah bisa menerapkannya sebelum keberangkatan, seperti aklimatisasi dan adaptasi pola sehari-hari. Dengan upaya ini, diharapkan ketika sudah sampai di tanah suci, CJH sudah dapat beradaptasi dengan perbedaan suhu yang terjadi, serta dapat melakukan upaya pencegahan yang sebenarnya sehingga heat stroke tidak terjadi.

\section{SARAN}

Kegiatan pendidikan kesehatan ini perlu dilakukan setiap musim haji, sekitar 1-2 bulan sebelum keberangkatan, bersamaan dengan manasik haji di tingkat kecamatan (KUA), sehingga pendidikan kesehatan bisa dilakukan secara berulang. Oleh karena itu diperlukan kerja sama lintas sektoral dengan Kantor Kementerian Agama Kabupaten/Kotamadya, khususnya dengan kepala Kantor Urusan Agama (KUA) kecamatan.

\section{DAFTAR PUSTAKA}

DerSarkissian, C. (2016). Heat Stroke: Symptoms and Treatment. https://www.webmd.com/a-to-zguides/heat-stroke-symptoms-andtreatment. 18 September 2016 sitasi tanggal 9 Oktober 2017

Gaudio, F.G., Grissom, C.K. (2015). Cooling Methods in Heat Stroke. Journal of Emergency Medicine. https://doi.org/10.1016/j.jemermed.2015. 09.01431 Oktober 2015 sitasi 20 Oktober 2017

Kemenkes R.I. (2017). 5 Langkah Cegah Sengatan Panas (Heat Stroke) Jemaah Haji di Arab Saudi. 22 Mei 2017. www.depkes.go.id/article/view/1705220 0010/5-langkah-cegah-sengatan-panasheat-stroke-jemaah-haji-di-arabsaudi.html sitasi tanggal 20 Oktober 2017

Leon, L.R., Helwig, B.G. (2010). Heat Stroke: Role of the Systemic Inflammatory Response. Journal of Applied Physiology.

https://doi.org/10.1152/japplphysiol.0030 1.201001 Desember 2010 sitasi 9 Oktober 2017

Mayo Clinic (2015). Heatstroke-Symptoms and Causes. https://www.mayoclinic.org/diseasesconditions/heat-stroke/symptomscauses/syc-20353581? $\mathrm{p}=1 \quad 15$ Agustus 2017 sitasi tanggal 20 Oktober 2017

National Health Sciences (NHS). (2015). Heat exhaustion and Heatstroke. https://www.nhs.uk/conditions/heatexhaustion-heatsroke/ 12 Januari 2018 sitasi tanggal 20 Januari 2018

Nikodemus, H. (2016). Jemaah Haji Berisiko Terkena 'Heatstroke'. https://amp.rappler.com/indonesia/10229 2-kementerian-kesehatan-jamaah-hajiindonesia-risiko-heatstroke 21 September 2016 sitasi tanggal 20 Oktober 2017 
Ono, Masaji. (2013). Heat Stroke and the Thermal Environment. Journal of the Japan Medical Association. JMAJ 56(3): 199-205, 2013. sitasi 20 Oktober 2017 